\title{
EL FULGOR VENIDO DE OTRA PARTE: BAUDELAIRE, MALLARMÉ, RILKE, GHAR, GELAN, LLANSOL
}

\section{Antoni Gonzalo Carbó (Universitat de Barcelona)}

Recibido el 30/6/2018. Aceptado el 18/4/2019.

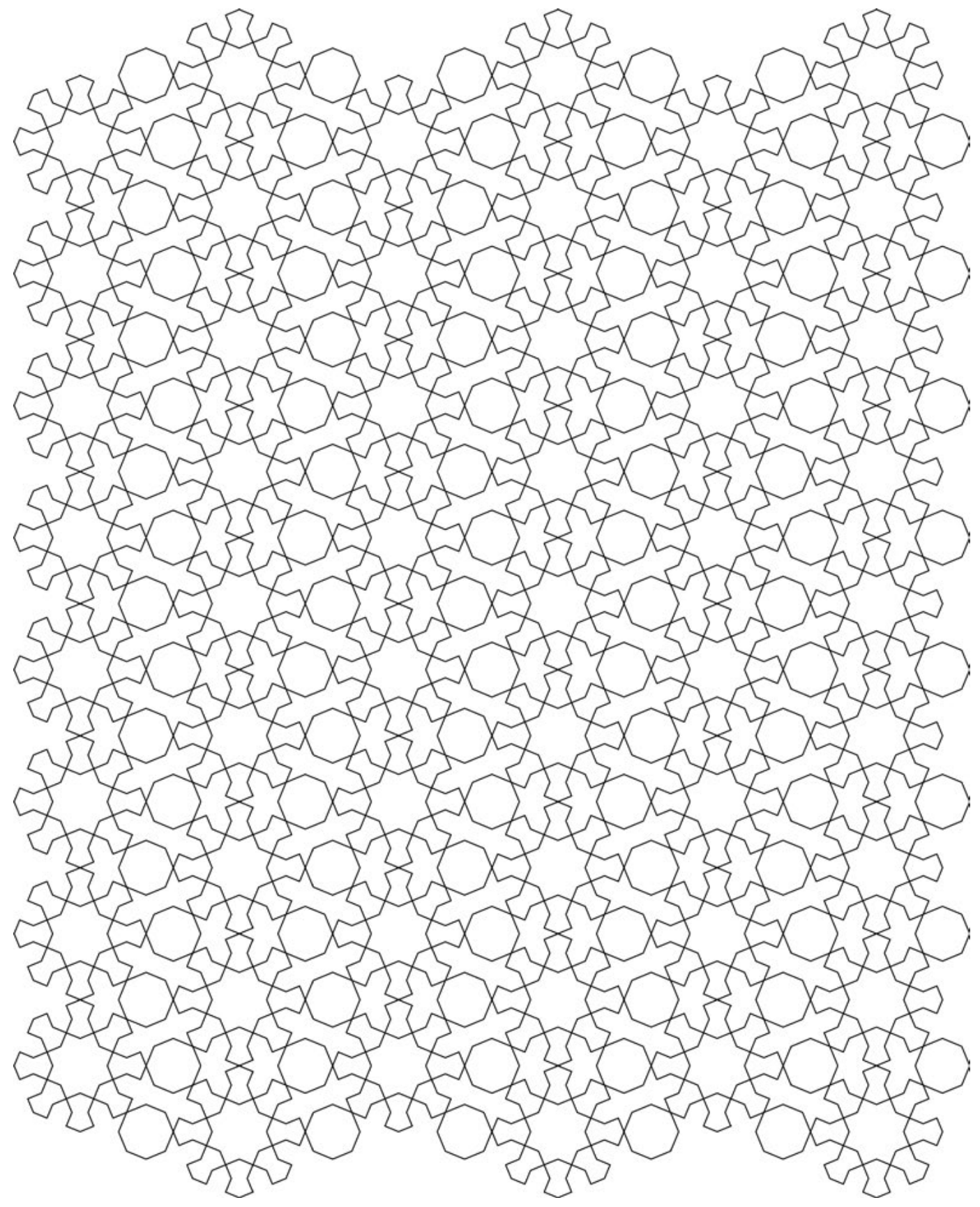


Resumen: Hay un fulgor que va unido a la extinción de sí. En el poema LV del Tarğumān de Ibn Arabī, la aniquilación del primer dístico encuentra su cénit en la contemplación extática del tercero en forma de fulgor: «El deseo me aniquila cuando estás ausente /.../ Pues siempre que Le hallo, contemplo una figura... en esplendor...». Su expresión poética moderna se halla en el verso de Les Noces d'Hérodiade, de Mallarmé, en el que Herodías lanza la cabeza de San Juan por la ventana: «fusqu’à l’horizon mort en un dernier éclat». El «Cántico de San Juan» es el himno de la cabeza cortada volando, del filo de la guadaña a la luz, hacia el «pur regard». Tomado como punto de partida la importancia que la expresión le vieil éclat tiene en su obra poética, se establece una arqueología de estas palabras en la poesía moderna y contemporánea: feu clair (Baudelaire), éclair absolu (Mallarmé), weißer Glanz (Rilke), glow more intense (Eliot), relâmpago intimo (Pessoa), mort (éclair)ante (Char), «fulgurante entrevisión»(Lezama), Schimmer des Urlichts (Celan), fulgor inapreensível (Llansol).

Palabras clave: Fulgor. Ibn 'Arabī. Maria Gabriela Llansol. Literatura de los siglos XIX y XX. Pierre Boulez.

Abstract: There is a glare that goes together with the extinction of the self. In the poem LV, from the Tarğumān, by Ibn 'Arabī, the annihilation of the first distich finds its zenith in the ecstatic contemplation of the third in the form of glare: «Desire annihilates me when you are absent / ... / For whenever I find Him, I contemplate a figure... in splendour...». Its modern poetic expression is found in the verse of Les Noces d'Hérodiade, by Mallarmé, in which Herodias throws the head of Saint John through the window: «fusqu'à l'horizon mort en un dernier éclat». The «Canticle of St. John» is the hymn of the severed head flying, from the edge of the scythe to the light, towards the «pur regard». Taken as a starting point the importance that the expression le vieil éclat has in his poetic work, an archaeology of these words is established in modern and contemporary poetry: feu clair (Baudelaire), éclair absolu (Mallarmé), weißer Glanz (Rilke), glow more intense (Eliot), relâmpago íntimo (Pessoa), mort (éclair) ante (Char), fulgurante entrevision (Lezama), Schimmer des Urlichts (Celan), fulgor inapreensível (Llansol).

Keywords: Glare. Ibn 'Arabī. Maria Gabriela Llansol. Literature of the 19th and 20th centuries. Pierre Boulez. 
El sosiego inmutable de ese blanco fulgor.

Stéphane Mallarmé, "Tristesse d'été (sonnet)»,

Du parnasse contemporain

Fulgor extremo: estoy ciego...

Georges Bataille, La experiencia interior

Fulgor inapreensível...

Maria Gabriela Llansol, Ardente texto Foshua

Gostaria que sobrevivesse a afirmação de que nós somos epifanias do mistério [...]

Maria Gabriela Llansol, Onde vais, drama-poesia?

Éclat es un término clave en la poesía de Stéphane Mallarmé, en la música de Pierre Boulez, en la antropología espiritual de Michel de Certeau. El gran compositor y director de orquesta francés tiene dos obras que hacen referencia a este término mallarmeano: Éclat (1964), composición de música instrumental, de nueve minutos, para quince instrumentos (nueve instrumentos de teclado o percusión, dos instrumentos de cuerda, dos de metal y dos de viento); Éclat-Multiples (1967-70), para gran orquesta, obra de música orquestal que es un desarrollo de la pequeña partitura de Éclat ${ }^{1}$.

La presencia que la obra de Mallarmé - poeta y crítico francés que representa la culminación y, al mismo tiempo, la superación del simbolismo francés - tiene en Pierre Boulez, podría reconocerse como una relación crucial en el largo camino creativo del compositor, hasta el punto de poder afirmar que toda su obra puede entenderse como un diálogo construido sobre los presupuestos de la poética mallarmeana. Toda la obra de Boulez puede ser vista como una inmensa lógica de lo in-audito.

Boulez trabajaba en su casa de Baden-Baden rodeado del canto de los pájaros que tanto inspiraba a su maestro - aniquilado en su ultra-exigencia -, Olivier Messiaen. «Pli selon plì, portrait de Mallarmé (1957-62, rev. 1989) es una obra de Boulez, para soprano y orquesta, basada en poemas de Stéphane

1 Cf. Robert Piencikowski, «"Assez lent, suspendu, comme imprévisible”. Einige Bemerkungen zu den Vorarbeiten zu Pierre Boulez, Éclat», en: Felix Meyer (ed.), Quellenstudien II: Zwölf Komponisten des 20. Jahrhunderts, Winterthur, Amadeus, 1993, pp. 97-116; versión francesa: id., «"Assez lent, suspendu, comme imprévisible": quelques aperçus sur les travaux d'approche d'Éclat», Genesis, n. ${ }^{\circ}$ 4, 1993, pp. 51-67. 
Mallarmé2. Su composición se inició en 1957; la misma ha tenido varias versiones y varias revisiones hasta 1989. Una primera versión completa (con las cinco partes actuales) fue creada en 1960, en Colonia, bajo la dirección del propio Boulez. Una nueva versión fue creada en 1962, también bajo la dirección del compositor. La obra está compuesta de cinco partes. Nos interesa resaltar aquí la segunda parte, la Improvisation sur Mallarmé I: «Le vierge, le vivace et le bel aujourd'hui», porque está basada en el soneto del mismo título: «iEl virgen, el vivaz y el bello hoy tan hermoso!». El momento de escribir este soneto - uno de los más famosos poemas del autor - publicado en 1885, no se conoce. La mayoría de los comentaristas ven en la imagen del cisne al poeta que lucha contra el «invierno» de la esterilidad. Nosotros nos detenemos en dos líneas del poema, en concreto los términos - blanche agonie (blanca agonía), pur éclat (puro destello) ${ }^{3}$ - porque reflejan muy bien lo que, a nuestro entender, podría constituir una declaración de autodisolución, o en términos mallarmeanos de auto(abolición), mort-éclair (muerte-destello) ${ }^{4}$ en la blancura abisal de lo invisible. Pli selon pli es, pues, en cierto modo un canto del cisne. Un canto final, algo elegíaco, acaso reflexivo sobre el oficio artístico (poético/musical). Néant sonore (Nada sonora): «creux néant musicien» («hueca nada musicante») 5 .

De forma retro-proyectiva analizamos la presencia de este término en escritores relevantes que, de forma más o menos explícita, pudieron influir en el sentido que a este término y sus compuestos (cena fulgor, fulgor inapreensível...) le otorga la autora que nos ocupa: Maria Gabriela Llansol. La hipótesis de trabajo es rastrear este término y sus sinónimos (destello, fulguración, relámpago...) en la literatura de los siglos XIX y XX (de Baudelaire a Valente, de Mallarmé a Lezama, de Rilke y Kafka a Celan,

2 El título, Pliegue tras pliegue, procede de un soneto del propio Mallarmé, escrito como responso a su amigo el poeta Villiers de L'Isle Adam, en donde habla de desbrozar la vetustez de las edificaciones de la ciudad de Brujas, desgajando su neblinosa existencia «pliegue tras pliegue». El soneto se titula "Remémoration d'amis belges». También Pierre Boulez pretende, según confiesa, ir aproximándose al universo poético de Mallarmé, desgajándolo pliegue tras pliegue. Cf. Philippe Albèra (dir.), Pli selon pli de Pierre Boulez. Entretien et études, Ginebra, Contrechamps, 2003, p. 35, n. 13; Yves Bonnefoy, «Mallarmé: La musique de l'intellect», en: Claude Samuel (dir.), Éclats/Boulez, París, Éditions du Centre Pompidou, 1986, pp. 96-98; Mary Breatnach, Boulez and Mallarmé. A Study in Poetic Influence, Ashgate, Aldershot, Brookfield, Scholar Press, 1996; Erling E. Guldbrandsen, «Playing with transformations: Boulez’s Improvisation III sur Mallarmés, en: Erling E. Guldbrandsen, Julian Johnson (eds.), Transformations of Musical Modernism, Cambridge, Cambridge University Press, 2015, pp. 223-244; id., «Casting New Light on Boulezian Serialism: Unpredictability and Free Choice in the Composition of Pli selon pli - portrait de Mallarmé», en: Edward Campbell, Peter O'Hagan (eds.), Pierre Boulez Studies, Cambridge, Cambridge University Press, 2016, pp. 193-220.

3 Stéphane Mallarmé, Stéphane Mallarmé en castellano II: Poesías, seguido de Otras poesías/Anécdotas o poemas/Igitur/Una jugada de dados, trad. R. Silva-Santisteban, Lima, Pontificia Universidad Católica del Perú, 1998, pp. 160-161.

4 Cf. Jean-Pierre Richard, L'univers imaginaire de Mallarmé, París, Seuil, 1961, pp. 196, 205-206, $212-$ 213, 291.

5 S. Mallarmé, «Une dentelle s'abolit...» («Entre la duda del supremo...»), en: Stéphane Mallarmé en castellano II, cit., p. 183. Cf. Éric Benoit, Néant sonore. Mallarmé ou la traversée des paradoxes, Ginebra, Droz, 2007, p. 11. 
de Bataille a Char) y deducir su influjo más o menos explícito en la obra llansoliana. No menos relevante es el empleo que la espiritualidad musulmana hace de este término en el contexto del sufismo, al que tanto alude la escritura de Llansol a través de autores como Hallāğ o Ibn 'Arabī.

Nuestra mención a Mallarmé y a Rilke está fundada en el hecho de que Llansol dejó versiones originales de nueve autores en lengua francesa: Verlaine, Rilke, Baudelaire, Rimbaud, Apollinaire, Éluard, Mallarmé, Pierre Louÿs y Thérèse de Lisieux. Llansol escribió siempre fuera del universo institucional y mediático de la literatura, asimilando su propio texto a un gran número de figuras de la cultura occidental europea, así como a autores orientales.

En la literatura portuguesa contemporánea, la obra de Llansol destaca con un perfil opuesto a la representación dominante en la novela y a todas las formas de la ortodoxia. Escrito bajo el signo de la ruptura, el texto está estructurado en forma no lineal y no secuencial, generando a menudo fulgurações (fulguraciones), o cenas de fulgor (escenas de fulgor), que traducen la discontinuidad temporal, la preferencia por lo fragmentario y la experiencia de la metamorfosis y la vibración de la vida originalmente puestas en el lenguaje. Una experiencia de escritura a la que Llansol no llama literatura - «No hay literatura. Cuando se escribe sólo importa saber en qué realidad se entra y si hay técnica adecuada para abrir caminos a otros». También por ello, a la verosimilitud contrapone el fulgor, focos de luz que se van encendiendo en el texto, «lugares vibrantes» que orientan a quien lee - «Mi texto no avanza por desarrollos temáticos, ni por trama, sino que sigue el hilo que une las diferentes escenas fulgon»; "La escritura que cultivo [...] separa lo inerte de lo fulgorizable. Todo lo que es fulgorizable integra lo vivo» ${ }^{6}$.

Tomado como punto de partida la importancia que la expresión le vieil éclat (el viejo fulgor) tiene en el Hérodiade (Herodías) de Stéphane Mallarmé, o el término éclat a secas - en su doble sentido: lo que estalla y lo que ilumina; éclair-éclat, a un tiempo aniquilando las cosas del campo de la visión y anonadando al instante al testigo de contemplación -, en el conjunto de la obra del estudioso de la mística Michel de Certeau, se establece una arqueología de estas palabras, o de sus sinónimos, en la poesía moderna y contemporánea (Baudelaire, Mallarmé, Rilke, Char, Lezama Lima, Celan, Valente). Para analizar la tradición de este término y sus sinónimos, se parte de un bello poema del gran místico y poeta andalusí Muhȳì al-Dīn Ibn al- 'Arabì (m. 638/1240), considerado como el más grande de los místicos musulmanes - también llamado al-Šayh al-Akbar (Máximo maestro) -, perteneciente al Tarğumān al-ǎ̌w $\bar{a} q$ (El intérprete de los deseos), una de las más claras cumbres de la literatura espiritual musulmana. Este poema comienza con dos significativos versos:

Añoró el Oriente al ver por el Este el rayo, mas si por el Oeste hubiese lucido, el Occidente habría anhelado. "iMi pasión es por los rayos y sus fulgores, no por los lugares ni la tierra!"”

6 Maria Gabriela Llansol, El libro de las comunidades, Madrid, Vision Net, 2005, p. 114. Las citas se encuentran en este libro de Llansol, en el epílogo de Maria Etelvina Santos.

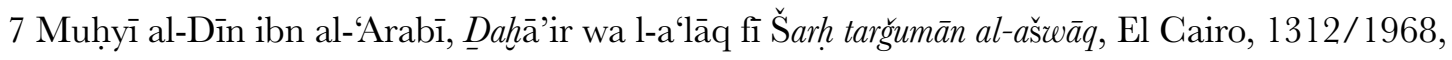


El tema central de este poema es el de las teofanías y la visión extática de Dios. Trata igualmente de los modos y formas bajo las que aquellas aparecen, así como su doble carácter «real» y «subjetivo». $E l$ primer verso se refiere a la «uisión» de Dios (ru’yat al-Haqq), a través de sus manifestaciones en la existencia y los acontecimientos. El Este representa el lugar de la manifestación fenoménica (mawdi kawnī). Por «Si por el Oeste hubiese lucido», alude a que, tras la manifestación de la Esencia Divina en el corazón del gnóstico, éste hubiese querido permanecer en el mundo de la trascendencia pura (tanzīh) y del misterio oculto $(\dot{\mathrm{g}} a y b)$, pero su naturaleza humana le hace volver a la batalla diaria de la materia. El segundo verso es consecuencia del anterior: desea las moradas (mawātin), no como lugar físico, sino como tópos virtual y ocasión de la teofanía. Estas imágenes «pertenecen al terreno intermedio (barzah), fronterizo, de la manifestación sutil, por el que, de manera misteriosa, en una grieta del tiempo y del espacio, surcada por relámpagos (burū $q$ ), fulgores y tinieblas, sincopada por dolorosos sobresaltos y cálidos hallazgos, se inscribe el Tarğumān»".

Asimismo, otro bello poema versa sobre el deseo insatisfecho por la ausencia del Bienamado, el deseo presente y el lejano. Aquí el místico contempla una visión que aumenta / la mayor unión, fulgor y majestad en su belleza». La aniquilación del primer dístico encuentra su cénit en la contemplación extática del tercero en forma de esplendor o de fulgor. El poema dice así:

El deseo me aniquila cuando estás ausente y hallarte no me alivia.

iSon (gemelos) pues los deseos, tanto en la lejanía como en la presencia!

Encontrarme con Él me trae cuanto nunca imaginé: ¡Una pasión

aún más fuerte [el éxtasis] es el (único) remedio!

Pues siempre que Le hallo, contemplo una figura que en su belleza aumenta, tanto en esplendor como en majestad.

Remedio no hay para la pasión, que hacia la total armonía (Niẓ̄m) pareja crece a la belleza. ${ }^{9}$

14:1-2 [Trad. cast.: El Intérprete de los Deseos (Tarŷumān al-Ašwāq), trad. G. Varona Narvión, Murcia, Editora Regional de Murcia, 2002, poema XIV: «El mensaje del viento», vv. 1-2, p. 133]. Véanse las traducciones al inglés [The Tarjumán al-ashwáq, A Collection of Mystical Odes by Muhyiddín Ibn alArabi, trad. R. A. Nicholson, reimpr., Londres, Theosophical Publishing House, [1911], 1978, pp. 74-76] y al francés [L'interprète des désirs (Turjumân al-Ashwâq), trad. del ár., pres. y nn. M. Gloton, París, Albin Michel, 1996, pp. 146-152]. Véase, a su vez, el poema titulado «El rayo oriental», en: Pablo Beneito (selecc., pres. y trad.), La taberna de las luces. Poesía sufi de al-Andalus y el Magreb (del siglo XII al siglo XX), Murcia, Editora Regional de Murcia, 2005, p. 7.

8 Carlos Varona Narvión, «La aparición del cuerpo invisible: apuntes para una anatomía mística en el Tarŷumān al-Ašrwāq», en: M. Ibn al-'Arabī, El Intérprete de los Deseos, cit., c. II, p. 55.

9 M. Ibn al-'Arabī, «El deseo presente y el lejano» [poema LV], en El Intérprete de los Deseos, cit., p. 235; id., The Tarjumán al-ashwáq, cit., pp. 141-142; id., L’interprète des désirs, cit., pp. 424-426. 
Como en todo el Tarğumān, estos dísticos se ocupan de manera central de las teofanías en el corazón del gnóstico, así como de la dialéctica de éste con el Tú divino. El buscador se encuentra en su deseo

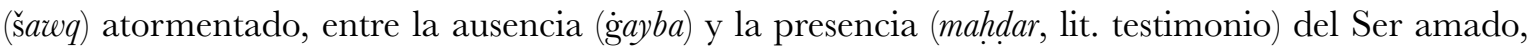
pues ni en una ni en otra encuentra paz, ya que estos opuestos cambian y se alternan de forma inesperada, como en toda relación amorosa, de ahí el título general de la obra: El intérprete de los [ardientes]

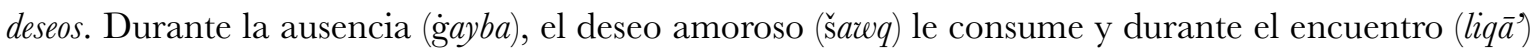
la incitación al deseo ardiente (ǐ̌tiy $\bar{a} q)$ le consume igualmente; él no cesa pues de estar atormentado. Cuando el encuentro (liq $\left.\bar{a}^{\prime}\right)$ tiene lugar se acrecienta $(y a z \bar{\imath} d)$ su éxtasis amoroso (wağ $\left.\underline{d} \hat{\imath}\right)$; accede a una condición sublime ('ali $)$ que se remonta casi sin fin (min 'al̄ $\bar{\imath} l \bar{a}$ 'ală), identificándose a su Objeto amoroso, lo que no deja sin embargo de acrecentar su dolor (fayazìd ālamahu). Es la enfermedad de estar separado que, como podemos ver a través de Michel de Gerteau, genera un profundo sentimiento de duelo. Y durante los tormentos de la ausencia, el místico espera obtener la curación por medio del encuentro. Pues cuando el encuentro tiene lugar, su éxtasis amoroso (wă̆ $d$ ) se intensifica.

Ibn 'Arabī se ha explicado detalladamente sobre sus símbolos preferidos: ruinas, campamentos, lagos, jardines, praderas, casas, flores, nubes, relámpagos, céfiros, colinas, arboledas, senderos, amigos, ídolos, mujeres que se levantan como soles ${ }^{10}$.

Partiendo de los poemas mencionados de Ibn 'Arabī, se puede llegar al «absoluto fulgor» de una línea de José Ángel Valente ${ }^{11}$, o sus símiles - cena fulgor (escena fulgor), fulgor inapreensível (fulgor inaprehensible) o fulgorizar, fonte de luz intensa (fulgorizar, fuente de luz intensa) - en la obra de Maria Gabriela Llansol (fulgor como el del poema «Das Einhorn» [ «El unicornio»] de Rilke, autor referente en nuestra escritora). En todos los autores mencionados encontramos un término u expresión afín: feu clair (fuego claro), Baudelaire; fulguration/éclair (fulguración/relámpago), blanc flamboiement (blanco resplandor), Mallarmé; Glanz (fulgor): «Du aber gründe ihn in deine Gnade, / in deinem alten Glanze pflanz ihn ein» ("Pero tú fúndale [a Dios] en tu gracia, / en tu fulgor antiguo plántale.»), en Rilke ${ }^{12}$; "Consumed by either fire or fire» ("por fuego y por el fuego consumidos»), en Eliot $^{13}$; «le grandissime éclair est tombé sur moi pour la première fois; plus rien n’a compté» («el grandísimo relámpago que ha caído sobre mí por primera vez, nada más ha contado»), en Char ${ }^{14}$; «dem Schimmer des Urlichts» («el fulgor de la luz primera»), en Celan ${ }^{15}$; «relâm-

10 Id., Dahăàir wa l-a 'lāq fì Šarh tarğumān al-ašwāaq, cit., p. 5.

11 José Ángel Valente, «El fulgor», XXXVI, en: Obras completas I. Poesía y prosa, Barcelona, Galaxia Gutenberg, Círculo de Lectores, 2006, p. 458.

12 Rainer Maria Rilke, El libro de horas (Das Stunden-Buch), trad. F. Bermúdez-Cañete, Madrid, Hiperión, 2005, p. 183.

13 T. S. Eliot, «Little Gidding», IV, v. 14, Cuatro cuartetos, en: Cuatro cuartetos, La roca y Asesinato en la catedral, ed. y trad. A. Jaume, Barcelona, Lumen, 2016, p. 135.

14 René Char, apud Paul Veyne, René Char en ses poèmes, París, Gallimard, 1990, p. 236.

15 Paul Celan, «Die Freigeblasene Leuchtsaat» («La siembra de luz a libre viento»), Fadensonnen (Soles

filamentos), en: Obras completas, trad. J. L. Reina Palazón, Madrid, Trotta, 1999, p. 298. 
pago intimo» (relámpago íntimo) (Pessoa) ${ }^{16}$; «muerte el relámpago en sus venas» ${ }^{17}$, "[...] la luminosidad la noche oscura de San Juan [de la Cruz], pues aquel rayo de conocer poético sin su acompañante noche oscura, sólo podría mostrar el relámpago de la cetrera actuando sobre la escayolada», «la luz de ese oscuro fulgor [...] nadie lo ha visto» (Lezama) ${ }^{18}$; «Sli, el fulgor: el rayo oscuro, la aparición o desaparición del cuerpo o del poema en los bordes extremos de la luz.» (Valente) ${ }^{19}$. De forma más o menos explícita, Lezama y Valente aluden así a la «luz oscura» de san Juan de la Cruz. Este calificativo otorga a luz una característica contradictoria, al menos en una primera impresión. En Rilke también encontramos esta asociación del fulgor y la oscuridad, en concreto en el poema «Der Knabe» («El muchacho») perteneciente a Das Buch der Bilder (El libro de las imágenes), cuando el poeta en dos versos hace referencia a «Oscuro, pero con un casco de oro, / de inquietante fulgor. [...]» ${ }^{20}$. En otro poema - «Das Einhorn» («El unicornio») -, en cambio, este fulgor está vinculado a la blancura última: «Weißer Glanz //...// so daß ein wenig Weiß / (weißer als alles) von den Zähnen glänzte» («blanco fulgor //...// un blanco más blanco que todo, en el brillo de sus dientes») ${ }^{21}$.

Hay un fulgor que va unido a la autoextinción. El punto de partida es un verso de Les Noces d'Hérodiade (Las nupcias de Herodías) de Stéphane Mallarmé en el que Herodías lanza la cabeza de San Juan por la ventana: «fusqu’à l'horizon mort en un dernier éclat» («al horizonte muerto en un postrer destello»)22. En Les Mots anglais Mallarmé, admira cómo, en el momento de morir, «la literatura, es decir, al menos la poesía, lanza intacto casi y original, un último y soberbio destello retrospectivo» ${ }^{23}$. Fulgor de muerte, último resplandor vinculado a ese cuerpo sacrificial decapitado ${ }^{24}$. En Le mort vivant (El muerto viviente),

16 Fernando Pessoa, Libro del desasosiego de Bernardo Soares, trad. Á. Crespo, Barcelona, Seix Barral, 1984, p. 48.

17 José Lezama Lima, «Muerte de Narciso», Verbum, n. ㄹ 2, 1937, p. 165.

18 Id., «Sierpe de don Luis de Góngora», en: El reino de la imagen, Caracas, Biblioteca Ayacucho, 1981, pp. 247, 256.

19 J. Á. Valente, «Notas de un simulador», III, en: Obras completas II. Ensayos, Barcelona, Galaxia Gutenberg, Círculo de Lectores, 2006, p. 461.

20 R. M. Rilke, El libro de las imágenes (Das Buch der Bilder), trad. J. Munárriz, Madrid, Hiperión, 2001, p. 53.

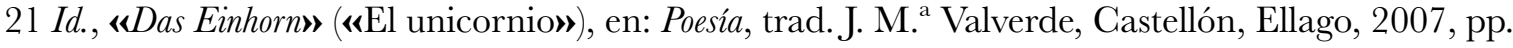
231-232. Cf. Karine Winkelvoss, Rilke, la pensée des yeux, París, Publications de l'Institut d'Allemand, Université de la Sorbonne Nouvelle, 2004, pp. 230, 289, 306-307, 325.

22 S. Mallarmé, Stéphane Mallarmé en castellano II, cit., p. 273. Cf. J.-P. Richard, L'univers imaginaire de Mallarmé, cit., p. 213.

23 S. Mallarmé, Euvres complètes, ed. H. Mondor, G. Jean-Aubry, [Tours], Gallimard, 1951, p. 911.

24 Sobre el tema de la decapitación en Mallarmé véanse: J. D. Hubert, «Representations of Decapitation: Mallarmé's "Hériodade" and Flaubert "Hérodias"», French Forum, vol. 7, n 3, septiembre 1982, pp. 245-251; Bertrand Marchal, La religion de Mallarmé. Poésie, mythologie et religion, [París], José Corti, 1988, pp. 515-516; J.-P. Richard, L'univers imaginaire de Mallarmé, cit., pp. 199, 212-213, 227; M. Robillard, Le désir de la vierge. Hérodiade chez Mallarmé, Ginebra, Droz, 1993, pp. 13, 83, 108, 151-153. 
$\vdots$

perteneciente a los Contes Indiens (Cuentos indios), Mallarmé cuenta la historia de un rajá condenado cada día a morir y a renacer (le mort vivant), y a no amar a su joven esposa más que entre dos eclipses mortales. Y Mallarmé evoca así los momentos amorosos que preceden a la desaparición necesaria. A propósito de El muerto viviente, Mallarmé emplea la expresión: «illuminant ma mort» («iluminando mi muerte» $)^{25}$. De nuevo el fulgor vinculado a la muerte como liberación. Maurice Blanchot, atinado intérprete de Mallarmé, habla de «el resplandor de la desaparición» ${ }^{26}$. Fulguration/éclair (fulguración/relámpago) es una imagen que es frecuente en los versos de Mallarmée ${ }^{27}$ como experiencia de desposeimiento y muerte simbólica ${ }^{28}:$ «D u cachot fulguré pour s'ensevelir où.?» («ंdel nicho fulgurado para ocultarse dónde?») $)^{29}$. En Las nupcias de Herodías es la destrucción que la espada corta culmina en su suicide («suicida») fulguration («fulguración») ${ }^{30}$; muerte deslumbrada.

Todo el lenguaje experiencial místico busca manifestar a un Ausente, y toda la mística es la narración de una pérdida, y sus desbordamientos no son enunciados sino destellos, resplandores (éclats) de una anunciación: la presencia que falta, saber de duelo. Pero lo que presenta el poema es la ex-posición de una presencia nómada y errátil, la orientación que se libra a la inmanencia de lo extraño desde un lugar que carece de estancia, desde un tiempo a la deriva, desarraigado e intempestivo. El discurso convoca a un encuentro con lo ausente: «[...] Fulgor y arañazo de lo que pasa pero no está ahí $[\ldots]{ }^{31}$.

El proceder de Lezama Lima favorece la ceguera por la que se ingresa en el orden previo al significado, es decir, señala los límites hacia los que la poesía implacablemente nos dirige, que no se pueden descartar sólo porque de ordinario escapan a nuestra percepción. "Toda materia tocada despide como un fulgor, su herida de costado, por la que se ve y penetra.»32. El ejercicio verbal apunta hacia la «latitud de la palabra», según denominación de José Ángel Valente, donde se roza el misterio. Se trata de la «entrevisión» o sacudida del relámpago lezamianas evocadas en Notas de un simulador:

25 Stéphane Mallarmé, Cuentos hindúes, trad. R. Silva-Santisteban, Lima, Pontificia Universidad Católica del Perú, 2008, p. 133.

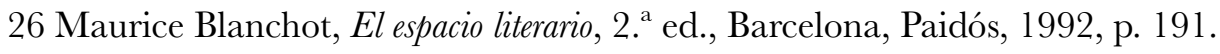

27 Cf. Robert Greer Cohn, Toward the Poems of Mallarmé, Cambridge, Berkeley, Los Ángeles, Cambridge University Press, University of California Press, 1965, p. 82; cf. Robillard, Le désir de la vierge, cit., p. 174; id., Sous la plume de l'ange. De Balzac à Valéry, Ginebra, Droz, 1997, p. 67.

28 Según Paul Bénichou, Mallarmé es «el hombre encargado de ver divinamente». Paul Bénichou, Selon Mallarmé, París, Gallimard, 1995, pp. 49-50.

29 S. Mallarmé, Stéphane Mallarmé en castellano II, cit., p. 275.

30 Ibid., p. 305.

31 Michel de Certeau, La fábula mística (siglos XVI-XVII), Madrid, Siruela, 2006, p. 53.

32 J. L. Lima, «Pascal y la poesía», en Tratados en La Habana, La Habana, Universidad Central de Las Villas, 1958, p. 179. 
"M'illumino / d'immenso": Ungaretti33. Imprevista y súbita y total fulguración del objeto poético, que Joyce creía también posible en la prosa y a la que proponía llamar epifanía.

Lezama Lima - el grande e inolvidable maestro - definió memorablemente, en el último ensayo de Tratados en La Habana, libro de 1956, la súbita - no extinguible - epifanía de lo poético: "fulgurante entrevisión, instante del relámpago en la piedra"34.35

En la revelación (denominada en otros pasajes por Valente «epifanía»), se asiste a la irrupción repentina e instantánea de una imagen que escapa a toda totalización discursiva (no procede del discurso, aunque, posteriormente, puede insertarse en él), pues es ella la que reclama ser un todo por sí misma. Ha de ser percibida - tal como afirma Valente del poema, que es el «lugar de la fulgurante aparición de la palabra» - «no en la mediación del sentido, sino en la inmediatez de su repentina aparición» ${ }^{36}$.

En el sufismo, el relámpago ${ }^{37}$ o el rayo (al-barq) expresa los centelleos de luz (lawämi ${ }^{\circ}$ que se manifiestan al adorador al inicio del recorrido de la senda. El relámpago lo incita entonces a entrar en la Presencia que confiere la proximidad (hadrat al-qurb) del Señor, con vistas al recorrido (sayr) en Dios ${ }^{38}$. En las primeras etapas, el relámpago se produce como un destello (lama'), una luz que despierta al creyente, y le impulsa a iniciar la Senda hacia Dios. En las etapas finales, se trata del primer atisbo de la Unicidad de la reunión (ahadiyya al-ğam ), de la cual deriva el anonadamiento [del viajero] en la Esencia sagrada de Dios. El relámpago hace referencia a los destellos de amor (lama ‘āt-i ‘išq) y a los brillos del anhelo (lamahāt-i šuq), cuya luz ilumina el corazón del viajero desde la Esencia más sagrada y las Presencias sagradas. Esta iluminación no es duradera y tiene lugar en los inicios del recorrido espiritual del enamorado.

Hemos constatado que los autores que nos ocupan vinculan este fulgor, que va unido al acto de «anihilar» o «aniquilar», «consumir» o «destricar», según el particular léxico de san Juan de la Cruz, a la muerte simbólica que precede a la contemplación: «fusqu’à l'horizon mort en un dernier éclat» («al horizonte muerto en un postrer destello») (Mallarmé) $)^{39}$, «el resplandor de la desaparición» (Blanchot, a partir de Mallarmé $)^{40}$, «estallidos de iluminación, suaves o fulgurantes», «es aquello por lo cual

33 Giuseppe Ungaretti, «Mattina», Allegria, 1919.

34 J. Lezama Lima, «La dignidad de la poesía», en: Tratados en La Habana, cit., p. 410.

$35 \mathrm{~J}$. Á. Valente, Notas de un simulador, III, IV, en: Obras completas II, cit., pp. 463, 465.

36 Id., Material memoria, Madrid, Alianza, 1992, p. 9.

37 Sobre el Relámpago como símbolo típico de la manifestación, revelación e iluminación divina cf. Ananda K. Coomaraswamy, El tiempo y la eternidad, Barcelona, Kairós, 1999, pp. 16-17, 103 n. 12.

38 'Alī b. Muḥammad al-Ǧurğān̄ī, Kìtāb al-Ta'rīfāt, trad. M. Gloton, Teherán, Presses Universitaires d'Iran, 1994, p. 103.

39 S. Mallarmé, Stéphane Mallarmé en castellano II, cit., p. 273. Cf. J.-P. Richard, cit., p. 213.

40 M. Blanchot, El espacio literario, cit., p. 191. 
"muero porque no muero"», «este espejo sediento de fulgor en que me he convertido» (Bataille) ${ }^{41}$, «muerte el relámpago en sus venas» (Lezama) ${ }^{42}$. «We only live, only suspire / Consumed by either fire or fire. » («Tan solo suspiramos, tan solo vivimos / por fuego y por el fuego consumidos.») ${ }^{43}$.

En el sufismo, el dikr (rememorar, es decir, mantener en el corazón, hacer presente al pensamiento, meditar $)^{44}$, la «conversación íntima entre el Señor y su fiel personal, es el verbo que purifica el corazón (árabe, qalb; persa, dil) y lo despoja de toda impureza, es lo que conduce al corazón al estado de perfecta transparencia en el que se convierte en la sede de las visualizaciones, de las fulguraciones y de los destellos de la «contemplación» mística (mušāhada). La «ciencia del corazón»se convierte en el órgano supremo de toda hermenéutica, es decir, en el ojo de las visiones suprasensibles, o mejor aún, en el órgano por el cual Dios se conoce a sí mismo, se revela en él mismo en las formas variadas de sus manifestaciones. Al principio estas luces se manifiestan como «resplandores» o iluminaciones fugitivas (burūq) y «destellos» (ár. lawāìh, per. lawāyih). Más perfecta se hace la transparencia (la especularidad) del espejo del corazón, a medida que estas luces aumentan, los «centelleos» o emanaciones (lawämi ${ }^{\circ}$ ) que ganan en duración y se diversifican hasta manifestar la forma de las entidades celestes. Una luz que brilla de forma prolongada es la del Corán o la del dikr.

Ya hemos visto que este fulgor vinculado a la experiencia interior reaparece en la literatura moderna y contemporánea. Resplandor venido de otra parte, como el que se vislumbra del otro lado de la puerta en «Ante la Ley» de Franz Kafka. En esta leyenda, que luego incorporó a la novela El proceso, se habla de un campesino que espera toda su vida a las puertas de la Ley para acceder a ella:

Por último se le debilita la vista y ya no sabe si la oscuridad reina de verdad a su alrededor o solo son sus ojos que lo engañan. Pero entonces advierte en medio de la oscuridad un resplandor que, inextinguible, sale por la puerta de la Ley. Le queda poco tiempo de vida. ${ }^{45}$

¿La laboriosa espera ante los guardias permite ver al fin "un resplandor que, inextinguible, sale por la puerta de la Ley"? Esta claridad, alusión kafkiana a la Shejiná de Dios en la tradición judía, podría ser quizás el fulgor de un deseo venido de otra parte. Pero no se entrega ni al trabajo ni a la edad. Es testamentaria: un beso de la muerte. ${ }^{46}$

41 Georges Bataille, La experiencia interior, seguida de Método de meditación y de Post-scriptum 1953, Madrid, Taurus, 1973, pp. 131, 132, 133.

42 J. Lezama Lima, «Muerte de Narciso», en: El reino de la imagen, cit., p. 5.

43 T. S. Eliot, «Little Gidding», IV, vv. 13-4, cit., p. 135.

44 Cf. Henry Corbin, La Imaginación Creadora en el Sufismo de Ibn 'Arabî, Barcelona, Destino, 1993, pp. 289-290, 423.

45 Franz Kafka, «Ante la Ley», en: Obras completas III. Narraciones y otros escritos, Barcelona, Galaxia Gutenberg, Círculo de Lectores, 2003, p. 193.

46 M. de Certeau, La fábula mística, cit., p. 12. (El subrayado es nuestro). 
Este absoluto fulgor aparece, asimismo, en el poema terminal del libro de José Ángel Valente titulado precisamente El fulgor. Es éste un libro sobre la transcendencia a través del cuerpo o sobre la materia a través de la mística. El lector en el umbral de la obra interpretará, quizá, la luz remota que brilla en el poema como el fulgor de la esperanza que guía al poeta hacia la salida del desierto, de la desolación, del sin nombre, de los estallidos de la noche. En otro poema anterior, la luz que llega es reverso, oscura claridad que lleva siempre más allá (al haz inalcanzable de este envés). En su misterio, el cuerpo es fulgor oscuro, misterio siempre insondable e inagotable: «desciende oscuro al fondo oscuro de tu luz.» ${ }^{47} \mathrm{La}$ «cegadora claridad» que culmina el poema (luz que es negra por su sobreabundancia) representa esta infinitud y constituye uno de los símbolos de El fulgor (y, en general, de toda la obra de Valente).

Es este estado de disponibilidad el que propicia la unión final. El fuego, junto a su sentido de purificación, simboliza también la pasión amorosa y en Valente (como se observa en «La memoria del fuego» ${ }^{48}$ ) la palabra divina. Es la transparencia (o estado de desnudez) la que hace posible que las palabras se pronuncien a sí mismas, el fuego de la palabra. Es el mismo símbolo que el empleado por san Juan de la Cruz en su «Llama de amor viva». Como en ésta, la unión sólo se alcanza a través de la noche, en un incendio sin fin: «Y todo lo que existe en esta hora / de absoluto fulgor / se abrasa, arde / contigo, cuerpo, / en la incendiada boca de la noche.» ${ }^{49}$.

Éclats, uno de los términos escogidos por Michel de Certeau, análogos, en su género, a las «palabras substanciales» de santa Teresa de Ávila. «Éclat» está próximo a la vez a lo que estalla y a lo que ilumina. «Éclair-éclat», como la irrupción de una mirada o de una imagen que trastorna. Algo parecido al antiguo y divino exaiphness, lo instantáneo platónico, lo «repentino» que rasga la nube para no volver: fugacidad del tránsito ${ }^{50}$. Su secreto escapa irresistiblemente y Certeau, al calificar su estilo, de hecho define la escritura que será la suya: «Un estilo atormentado, perforado constantemente por destellos pasajeros que manan en imprevisibles puntos del horizonte» ${ }^{51}$.

A propósito de la poesía de Mallarmé, Albert Thibaudet habla de «fulguraciones sucesivas»» ${ }^{52}$. Estas fulguraciones sucesivas, tanto en la obra de Mallarmé como en la de Maria Gabriela Llansol, la autora que nos ocupa, tienen por fin la exaltación del otro misterioso. Un tal ensueño, perdidamente tendido hacia la otra realidad, la ausente ${ }^{53}$. En la compilación de sus escritos en prosa titulada Divagaciones, Mallarmé alude varias veces a estas fulguraciones sucesivas que tan presente están, en parte

47 J. Á. Valente, «El fulgor», XXXIII, en Obras completas I. Poesía y prosa, cit., p. 456.

$48 I d$., «Variaciones sobre el pájaro y la red», en: Obras completas II, cit., pp. 430-434.

49 Id., Obras completas I. Poesía y prosa, cit., p. 458.

50 Cf. Stanislas Breton, «Le pèlerin, voyageur et marcheur», en: Luce Giard (dir.), Le voyage mystique. Michel de Certeau, París, Recherches de Science Religieuse, Cerf, 1988, p. 19.

51 Michel de Certeau, «De Saint-Cyran au jansénisme», Christus, vol. 10, n. o 39, 1963, p. 403.

52 Albert Thibaudet, La poésie de Stéphane Mallarmé. Étude littéraire, París, Gallimard, 1926, pp. 127-134.

53 Cf. Charles Mauron, Mallarmé l’obscur, París, José Corti, 1968, p. 150. 
$\vdots$

bajo su influjo, en la poesía contemporánea como relámpagos fugaces de un absoluto inalcanzable:

La obra pura, implica la desaparición elocutoria del poeta, que cede la iniciativa a las palabras, movilizadas por el choque de su desigualdad; se encienden con reflejos recíprocos como un virtual reguero de fuego sobre las pedrerías $[\ldots]$. Todo se vuelve suspenso, disposición fragmentaria $[\ldots]$ lo que sería el poema callado, en los blancos [...] En poesía, donde se impone una plenitud fulgurante [...], el mágico concepto de la Obra [alquímica].

Haber pensado en la quimera atestigua, en el reflejo de sus escamas, cuánto el presente ciclo, o último cuarto de siglo, padeció algún relámpago absoluto [éclair absolu] $[\ldots] .^{54}$

En la obra de Mallarmé las palabras se asocian, distantes e inconexas, en el firmamento del poema - signatura, fecha y firma de una estancia - como cuerpos astrales que se atraen en virtud de una desconocida fuerza gravitatoria. Esta fijación no produce ningún sentido estable, no representa sino la propia (r)emisión material y espaciotemporal de las palabras, esa (des-)aparición instantánea y opalescente de la noción pura que Mallarmé designa metafóricamente como un efecto de scintillation: un resplandor parpadeante o, literalmente, una variación en la intensidad de una inscripción:

$[\ldots]$ Los ojos se velan, y muere de nuevo. [...]

El difunto encerró, en estas palabras, un misterio, como su sepulcro, solo por él conocido. [...]

Fulgor [Scintillation] de toda mi intimidad; divina $\left[\ldots . .^{55}\right.$

Para experimentar este destello absoluto el poeta, como su Herodías, debe penetrar: «Sans fin dans de savants abîmes éblouis» («dentro de inmaculados abismos deslumbrantes») ${ }^{56}$. Asimismo, este fulgor revelador en la oscuridad es el que experimenta Rainer Maria Rilke, tal como deja escrito en la célebre línea de Das Stunden-Buch (El libro de horas): «Denn Armut ist ein grosser Glanz aus Innen...» ("Pues pobreza es fulgor, muy) grande, desde dentro.») ${ }^{57}$. Un resplandor que sale de dentro ${ }^{58}$. El poeta/monje es humilde, puesto que la tarea estética exige desasimiento, despersonalización. Rilke fue testigo de un modo de entender la religiosidad menos individualista y dogmático, al tiempo que mucho más vivo que en occidente, así como una concepción excepcional de la divinidad que él mismo denominó «la oscuridad de Dios» y que ya no habría de abandonar jamás el universo poético de Rilke. "La oscuridad de Dios» («das

54 Stéphane Mallarmé, «Crisis del verso», en: Stéphane Mallarmé en castellano III: Divagaciones, seguido de Prosa diversa/Correspondencia, trad. R. Silva-Santisteban, Lima, Pontificia Universidad Católica de Perú, 1998, p. 221.

55 Id., «Le mort vivant» («El muerto viviente»), en: Cuentos hindúes, cit., pp. 125, 127.

56 Id., «Las nupcias de Herodías. Misterio», en: Stéphane Mallarmé en castellano II, cit., p. 291.

57 R. M. Rilke, El libro de horas, cit., p. 193.

58 Cf. Mauricio Wiesenthal, Rainer Maria Rilke (El vidente y lo oculto), Barcelona, Acantilado, 2015, p. 378. 
Dunkel Gottes») y la «pobreza es fulgor, muy grande» («Armut ist ein grosser Glanz») constituyen los polos de lo oculto y el vidente, respectivamente.

Este último fulgor, resplandor suprasensible, tal como ya se ha visto, también aparece varias veces en la poesía de T. S. Eliot:

un resplandor que ciega a primera hora de la tarde.

Y un fulgor más intenso [And glow more intense] que el de las llamas o las brasas sacude el espíritu en letargo: no es viento sino fuego de Pentecostés ${ }^{59}$

«Si nous habitons un éclair, il est le cœur de l'éternel» («Si habitamos un relámpago, es el corazón de lo eterno»), confiesa René Char ${ }^{60}$, como el místico que recibe el despertar súbito o el asceta que consuma la salida fuera de sí: «L'éclair me dure. [...] La poésie me volera ma mort» («El relámpago me dura. [...] La poesía me robará la muerte» ${ }^{61}$. El relámpago esclarecedor, luz súbita que ilumina y, a la par, fulmina. Estas imágenes del rayo (foudre) y del relámpago (éclair) son frecuentes en la poesía de René Char ${ }^{62}$ : «Primer rayo que duda entre la imprecación del suplicio y el magnífico amor.» ${ }^{63}$ «Tormentosa libertad en los pañales del rayo, sobre la soberanía del vacío, en las manecitas del hombre.» ${ }^{64}$ «Oh gran timón negro, en camino hacia tu muerte, ¿por qué siempre habría de corresponderte a ti mostrar el relámpago?» ${ }^{65}$ «Enjambre, relámpago y anatema: tres líneas oblicuas hacia la misma cima. [...] No te quejes por vivir más cerca de la muerte que los mortales.» ${ }^{66}$ «Tú que naces perteneces al relámpago. Serás piedra de relámpago tanto tiempo como la tormenta se sirva de tu lecho para huir.» ${ }^{67}$ «El que iba delante se apoyó contra un fresno, tomó nota de la recidiva del rayo y aguardó la noche deseando.» ${ }^{68}$

El «Amigo silencioso» es el corazón del relámpago. Hay que estar en la oscuridad para descubrir los secretos de las tinieblas, hay que tocar el fondo de la desesperación para renacer a la vida. Precisamente porque la noche es para él la única realidad auténtica, es la razón por la cual el poeta está a la

59 T. S. Eliot, «Little Gidding», I, vv. 8-10, cit., p. 125.

60 R. Char, «À la santé du serpent» [Fureur et mystère], en: Euvres complètes, París, Gallimard, 1983, p. 266 [trad. cast.: id., Poesía esencial. Furor y misterio. Los Matinales. Aromas cazadores, ed. y trad. de J. Riechmann, Barcelona, Galaxia Gutenberg, Círculo de Lectores, 2005, p. 335].

61 Id., «La bibliothèque est en feu» [La Parole en archipel], en: Euvres complètes, cit., p. 378.

62 Sobre la imagen del «relámpago» (éclair) en la poesía de René Char véase la intr. de J. Roudaut en R. Char, Euvres complètes, cit., pp. XL-XLI.

63 R. Char, «El meteoro del 13 de agosto» [Furor y misterio], en Poesía esencial, cit., p. 341.

64 Id., «El meteoro del 13 de agosto», ibid., p. 343.

65 Id., «Rubor de los Matinales» [Los Matinales], id., p. 475.

66 Ibid., p. 483.

67 Id., «Excursión al pueblo» [Aromas cazadores], id., p. 505.

68 Id., «Bajo el follaje», [Aromas cazadores], id., p. 541. 
búsqueda de alguna luz y de los seres que la reflejan ${ }^{69}$. La esperanza que él suscita, el deseo de luz que da a las cosas, es el «sur-ressort» de su pesimismo, su manera de hacer fracasar su destino. El relámpago que atraviesa las tinieblas nos deslumbra mientras nos abre al mundo ignorado, el espacio inundado de luz. La poesía produce el mismo efecto. Es a la vez un sentimiento que nos arrebata y la revelación de una verdad que se deriva. La poesía produce lo que el conocimiento quiere guardar secreto. Pero su aparición es tan rápida como el destello de un rayo. El relámpago tan pronto nos ilumina como nos parte en dos. El poeta asume perpetuos y renacientes peligros. Cuando consigue hacernos compartir sus encuentros con el relámpago, cuando refiere sobre la página en blanco lo que ha entrevisto en las tinieblas de la ocasión, el poema brota como la llamarada de una hierba aromática que nos corta la respiración. Como para los ascetas y los místicos, su relámpago constituye una aurora del alma tras la noche de los sentidos: «la nuit noueuse qui précède et suit l'éclair» («la noche nudosa que precede y sigue al relámpago» $)^{70}$.

En la metáfora del relámpago se mueven con soltura tanto René Char como su obra. L'éclair au front (Un relámpago en la frente) es el título de una biografía que le dedicó Laurent Greilsamer ${ }^{71}$, corroborando así las palabras que Saint-John Perse le enviara en halagadora nota: «Char, acorralaste al relámpago en su nido, y sobre el relámpago fraguas». Y, ciertamente, sobre él fragua Char versos que le han hecho célebre: «Si habitamos un relámpago / es el corazón de lo eterno» o «el relámpago me dura». Entre lo instantáneo y la duración, entre lo oscuro y el deslumbramiento, esta poesía trata de crear una tensión en la que los contrarios se potencian.

En la misma línea se sitúa Paul Celan, admirador y traductor al alemán de la obra de Char. «Eine Hand mit dem Schimmer des Urlichts» («Una mano con el fulgor de la luz primera»), es una significativa línea del poema titulado «Die Freigeblasene Leuchtsaat» («La siembra de luz a libre viento») ${ }^{72}$. El término fulgor se repite varias veces en la escritura de Celan. El poeta emplea diversos sinónimos: Schimmer, Glanz... Así, en el siguiente verso del poema «Wo eis Ist» («Donde hay hielo»), el fulgor se muestra vinculado al hoyo que, a su vez, sugiere la muerte: «Ein Glanz lag über der Wuhne» («Un fulgor cubría el hoyo en el hielo») ${ }^{73}$. Y en otras dos líneas del poema «Weiss und Leicht» («Blanco y ligero»): «Los rayos. Nos soplan cumulándonos. / Llevamos el fulgor, el dolor y el nombre.» ${ }^{74}$.

En relación con los autores mencionados, cena fulgor es una emblemática expresión del mundo imaginal de la obra de Maria Gabriela Llansol que nos evoca el relâmpago íntimo de Fernando Pessoa:

69 Cf. Jean Voellmy, René Char ou le mystère partagé, Seyssel, Champ Vallon, 1989, p. 121.

70 R. Char, «Le Nu perdu» [Le Nu perdu], en: Euvres complètes, cit., p. 431.

71 Laurent Greilsamer, L’éclair au front. La vie de René Char, París, Fayard, 2004.

72 P. Celan, Obras completas, cit., p. 298.

73 Id., «Sieben Rosen Später» («Siete rosas más tarde») [Von Schwelle zu Schwelle (De umbral en umbral)], ibid., p. 89.

74 Id., «Weiss und Leicht» («Blanco y negro»), [Sprachgitter (Reja de lenguaje)], id., p. 126. 
Me he dado cuenta, en un relámpago íntimo, de que no soy nadie. Cuando brilló el relámpago, aquello donde había supuesto una ciudad era una llanura desierta [...]. Si tuve que reencarnar, he reencarnado sin mí, sin haber reencarnado yo. [...] Mi alma es un maelstrom negro, vasto vértigo alrededor del vacío, movimiento de un océano infinito en torno a un agujero de nada, $[\ldots]$ en un remolino siniestro y sin fondo. ${ }^{75}$

En Pessoa y en Llansol, el relámpago y el fulgor, respectivamente, están vinculados con la Nada: la «llanura desierta», «la tumba de Dios» (Libro del desasosiego), «No soy nada. Nunca seré nada. No puedo querer ser nada.» («Tabaquería») (Pessoa); la Nada de Dios (Eckhart, Pessoa, Llansol).

En un admirable poema de Fernando Pessoa, de secuencia de cinco, titulado «Além-Deus» («Más allá de Dios»), de carácter esotérico, se manifiesta el destello de lo ignoto, como muestran estos versos, que son los finales del cuarto de la serie:

¡Más allá de Dios! Negra calma...

Resplandor de Desconocido...

Todo tiene otro sentido, oh alma,

Incluso el tener-un-sentido... ${ }^{76}$

Estos vocablos van vinculados a una muerte simbólica y a una luz que viene d'ailleurs (de otra parte): blanche agonie // pur éclat («blanca agonía // puro destello»), «tú que te mueres [...] / ¡noche blanca de témpanos y de nieve cruel!» $\rangle^{77}$, «la Muerte balsámica» $»^{78}$ (Mallarmé), «un fulgor muy grande», «blanco fulgor» (Rilke), «una quieta luz blanca moviéndose» (Eliot) ${ }^{79}$, «muerte luminosa» (R. Char) ${ }^{80}$, mort éblouie [«muerte deslumbrada»] (M. de Certeau) ${ }^{81}$. En la poesía de Rilke, el grosser Glanz [fulgor muy grande], va unido a las ideas de la pobreza espiritual (Armut) y la muerte simbólica (Tod, Sterben): «Señor, da a cada cual la muerte que les es propia. El morir que de aquella vida nace //...// La gran muerte que todos llevan en sí, es el fruto $»^{82}$. Del feu clair (Baudelaire) al «fulgor inapreensível»(Llansol), en la poesía moderna y contemporánea estos términos simbolizan, de forma más o menos hermética, una mística de la transcendencia vacua. En ellos se rastrean los grados de elevación del alma de la tradición medieval, y como en la escala espiritual, el lenguaje se detiene en el límite extremo:

75 F. Pessoa, Libro del desasosiego de Bernardo Soares, cit., p. 48.

76 Id., apud Ángel Crespo, La vida plural de Fernando Pessoa, Barcelona, Seix Barral, 1988, p. 119.

77 S. Mallarmé, «Hérodiade» («Herodías»), en: Stéphane Mallarmé en castellano II, cit., p. 101.

78 Id., «Les Fleurs» («Las flores»), en: Stéphane Mallarmé en castellano II , cit., p. 55.

79 T. S. Eliot, «Burnt Norton», II, v. 27, cit., p. 193.

80 R. Char, En trente-trois morceaux, XXXII, en: Euvres complètes, cit., p. 779.

81 Michel de Certeau «Éxtasis blanco», en: La debilidad de creer, Buenos Aires, Katz, 2006, p. 316.

82 R. M., Rilke, El libro de horas, cit., p. 177. 
1) purificatio: va te purifier («purificate»), Baudelaire;

2) ascensio o elevatio: élévation («elevación»), Baudelaire; «N'AURA EU LIEU

/ une élévation ordinaire verse l'absence» ("HABRÁ TENIDO LUGAR / una elevación ordinaria vierte la ausencia») ${ }^{83}$, Mallarmé; Um falção no punho (Un halcón en el puño), Llansol, imagen con la que nuestra escritora parece hacer referencia al halcón blanco que, en la tradición del sufismo persa, es un símbolo del alma anhelante del adepto de la realización mística, de la elevada aspiración espiritual (ár. himma, per. himmat) ${ }^{84}$;

3) annihilatio: aboli[e], agonie («abolición», «agonía»), Mallarmé; «Der grosse Tod», «süssen Tod» («la gran muerte», "dulce muerte»), Rilke ${ }^{85}$; "We are born with the dead» («nacemos con los muertos»), Eliot ${ }^{86}$; «disolverse o desaparecer» ${ }^{87}$, «técnica de autodisolución o de autoabolición», «absoluta disolución», J. Á. Valente ${ }^{88}$; «seremos los dadores de nuestra propia / muerte», Llanso ${ }^{89}$, que no deja de ser una trasposición de la «muerte que le es propia» (seinen eignen Tod) de Das Stunden-Buch (El libro de horas) de Rilke ${ }^{90}$.

Luego el arco desciende: la obra sólo puede sonreír a su ideal, pero no lo alcanza.

83 S. Mallarmé, "Igitur ou la folie d’Elbehnon» ("Igitur ou la locura de Elbehnon»), en: Stéphane Mallarmé en castellano II, cit., p. 497.

84 Maria Gabriela Llansol, Um falção no punho, Lisboa, Relógio d'Água, 1985.

85 R. M. Rilke, El libro de horas, cit., pp. 177, 179.

86 T. S. Eliot, «Little Gidding», cit., p. 219.

87 José Ángel Valente, «7 de mayo de 1990», Diario anónimo (1959-2000), Barcelona, Galaxia Gutenberg, Círculo de Lectores, 2011, p. 270.

88 Id., «El sueño de Daniel», en: Obras completas II, cit., p. 1459.

89 Maria Gabriela Llansol, «Cuentos del mal errante», en: El litoral del mundo, trad. de Atalaire, [s. 1.], Chamán Ediciones, 2016, XXX, «Un ritual de gestos».

90 R. M. Rilke, El libro de horas, cit., p. 177. 


\section{REFERENGIAS BIBLIOGRÁFIGAS}

ALBÈRA, Philippe (dir.) (2003), Pli selon pli de Pierre Boulez. Entretien et études, Ginebra, Contrechamps. AL-ǦURǦGANI, 'Alī b. Muḥammad (1994), Kitāa al-Tárinfât, trad., intr. y nn. de Maurice Gloton, pref. de Pierre Lory, Teherán, Presses Universitaires d'Iran.

BATAILLE, Georges (1973), La experiencia interior seguida de Método de meditación y de Post-scriptum 1953, trad. de Fernando Savater, Madrid, Taurus.

BENEITO, Pablo (selecc., pres. y trad.) (2005), La taberna de las luces. Poesía sufi de al-Andalus y el Magreb (del siglo XII al siglo XX), Murcia, Editora Regional de Murcia.

BÉNICHOU, Paul (1995), Selon Mallarmé, París, Gallimard.

BENOIT, Éric (2007), Néant sonore. Mallarmé ou la traversée des paradoxes. Ginebra, Droz.

BLANGHOT, Maurice (1992), El espacio literario, 2. a ed., Barcelona, Paidós.

BONNEFOY, Yves (1986), «Mallarmé: La musique de l'intellect», en: Glaude Samuel (dir.), Éclats/ Boulez, París, Éditions du Centre Pompidou, pp. 96-98.

BREATNACH, Mary (1996), Boulez and Mallarmé. A Study in Poetic Influence, Ashgate, Aldershot, Brookfield, Scholar Press.

BRETON, Stanislas (1988), «Le pèlerin, voyageur et marcheur», en: Luce Giard (dir.), Le voyage mystique. Michel de Certeau, París, Recherches de Science Religieuse, Cerf.

CELAN, Paul (1999), Obras completas, pról. de Carlos Ortega, trad. de José Luis Reina Palazón, Madrid, Trotta.

CERTEAU, Michel de (2006), La debilidad de creer, Buenos Aires, Katz.

(2006), La fábula mística (siglos XVI-XVII), Madrid, Siruela.

(1963), «De Saint-Cyran au jansénisme», Christus, vol. 10, n. 39, 1963, pp. 399-417.

COHN, Robert Greer (1965), Toward the Poems of Mallarmé, Cambridge, Berkeley, Los Ángeles, Cambridge University Press, University of California Press.

COOMARASWAMY, Ananda K. (1999), El tiempo y la eternidad, Barcelona, Kairós.

CORBIN, Henry (1993), La Imaginación Creadora en el Sufismo de Ibn 'Arabî, Barcelona, Destino.

CRESPO, Ángel (1988), La vida plural de Fernando Pessoa, Barcelona, Seix Barral.

CHAR, René (2005), Poesía esencial, Furor y misterio. Los Matinales. Aromas cazadores, ed. bilingüe, trad., pról. y nn. de Jorge Riechmann, Barcelona, Galaxia Gutenberg, Círculo de Lectores.

(1983), Euvres complètes, intr. de Jean Roudaut, París, Gallimard.

ELIOT, T. S. (2016), Cuatro cuartetos, La roca y Asesinato en la catedral, ed. y trad. de Andreu Jaume, Barcelona, Lumen.

GREILSAMER, Laurent (2004), L'éclair au front. La vie de René Char, París, Fayard.

GULDBRANDSEN, Erling E. (2016), «Casting New Light on Boulezian Serialism: Unpredictability 
and Free Choice in the Composition of Pli selon pli-portrait de Mallarmé», en: Edward Campbell, Peter O’Hagan (eds.), Pierre Boulez Studies, Cambridge, Cambridge University Press, pp. 193-220.

(2015), «Playing with transformations: Boulez’s Improvisation III sur Mallarmé», en: Erling E. Guldbrandsen, Julian Johnson (eds.), Transformations of Musical Modernism, Cambridge, Cambridge University Press, pp. 223-244.

HUBERT, J. D. (1982), «Representations of Decapitation: Mallarmé's "Hériodade" and Flaubert "Hérodias"», French Forum, vol. 7, no 3, pp. 245-251.

IBN AL-ARABĪ, Muhyī al-Dīn (2002), El Intérprete de los Deseos (Tarŷumān al-Ašrwāq), trad., coment. y nn. de Carlos Varona Narvión, Murcia, Editora Regional de Murcia.

(1996), L'interprète des désirs (Turjumân al-Ashwwâq), trad. del ár., pres. y nn. de Maurice Gloton, pref. de Pierre Lory, París, Albin Michel.

(1978), The Tarjumán al-ashwáq, A Collection of Mystical Odes by Muhyi'ddín Ibn al-Arabi, trad. de Reynold A. Nicholson, pref. de Martin Lings. Reimpr, Londres, Theosophical Publishing House, [1911].

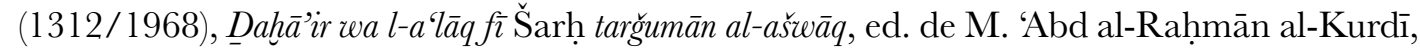
El Cairo.

KAFKA, Franz (2003), Obras completas III. Narraciones y otros escritos, ed. dir. por Jordi Llovet, trad. de Adan Kovacsics, Joan Parra Contreras, Juan José del Solar, pról. de Jordi Llovet, Barcelona, Galaxia Gutenberg, Círculo de Lectores.

LEZAMA LIMA, José (1981), El reino de la imagen, selecc., pról. y cronología de Julio Ortega, Caracas, Biblioteca Ayacucho.

(1958), Tratados en La Habana, La Habana, Universidad Central de Las Villas.

(1937), «Muerte de Narciso», Verbum, n. ${ }^{\circ}$ 2, pp. 163-168.

LLANSOL, Maria Gabriela (2016), El litoral del mundo, trad. del port. de Atalaire, [s. 1.], Chamán Ediciones.

(2005), El libro de las comunidades, trad. del port. y ed. de Atalaire, Madrid, Vision Net.

(1998), Ardente texto Joshua, Lisboa, Relógio d'Água.

(1985), Um falção no punho, pref. de Augusto Joaquim, Lisboa, Relógio d'Água.

MALLARMÉ, Stéphane (2008), Cuentos hindúes, pref. de Edmond Bonniot, trad. de Ricardo SilvaSantisteban, decor. en color de Maurice Ray, Lima, Pontificia Universidad Católica del Perú.

(1998), Stéphane Mallarmé en castellano II: Poesías seguido de Otras poesías/Anécdotas o poemas/Igitur/ Una jugada de dados, trad. y pról. de Ricardo Silva-Santisteban, Lima, Pontificia Universidad Católica del Perú.

(1998), Stéphane Mallarmé en castellano III: Divagaciones, seguido de Prosa diversa/Correspondencia, trad. de Ricardo Silva-Santisteban, Lima, Pontificia Universidad Católica de Perú.

(1951), Euvres complètes, ed. y nn. de Henri Mondor, G. Jean-Aubry, [Tours], Gallimard. 
MARCHAL, Bertrand (1988), La religion de Mallarmé. Poésie, mythologie et religion, [París], José Corti.

MAURON, Charles (1968), Mallarmé l'obscur, París, José Corti.

PESSOA, Fernando (1984), Libro del desasosiego de Bernardo Soares, trad. del port., organización, intr. y nn. de Ángel Crespo, Barcelona, Seix Barral.

PIENCIKOWSKI, Robert (1993), «"Assez lent, suspendu, comme imprévisible”, Einige Bemerkungen zu den Vorarbeiten zu Pierre Boulez, Éclat», en: Felix Meyer (ed.), Quellenstudien II: Zwölf Komponisten des 20. Fahrhunderts, Winterthur, Amadeus, pp. 97-1 16.

(1993), “Assez lent, suspendu, comme imprévisible": quelques aperçus sur les travaux d'approche d'Éclat», Genesis, n. ${ }^{\circ}$ 4, pp. 51-67.

RICHARD, Jean-Pierre (1961), L'univers imaginaire de Mallarmé, París, Seuil.

RILKE, Rainer Maria (2007), Poesía, trad. de José María Valverde, ed. de Jordi Llovet, Castellón, Ellago.

(2005), El libro de horas (Das Stunden-Buch), trad. y pról. de Federico Bermúdez-Cañete, ed. bilingüe, Madrid, Hiperión.

(2001), El libro de las imágenes (Das Buch der Bilder), trad. de Jesús Munárriz, ed. bilingüe, Madrid, Hiperión.

ROBILLARD, Monic (1997), Sous la plume de l'ange. De Balzac à Valéry, Ginebra, Droz.

(1993), Le désir de la vierge. Hérodiade chez Mallarmé, Ginebra, Droz.

SAMUEL, Glaude (dir.) (1986), Éclats/Boulez, París, Éditions du Centre Pompidou.

THIBAUDET, Albert (1926), La poésie de Stéphane Mallarmé. Étude littéraire, París, Gallimard.

VALENTE, José Ángel (2011), Diario anónimo (1959-2000), ed. de Andrés Sánchez Robayna, Barcelona, Galaxia Gutenberg, Círculo de Lectores.

(2006), Obras completas I. Poesía y prosa, ed. e intr. de Andrés Sánchez Robayna, Barcelona, Galaxia Gutenberg, Círculo de Lectores.

(2006), Obras completas II. Ensayos, ed. de Andrés Sánchez Robayna, recop. e intr. de Claudio Rodríguez Fer, Barcelona, Galaxia Gutenberg, Círculo de Lectores.

(1992), Material memoria, Madrid, Alianza.

VEYNE, Paul (1990), René Char en ses poèmes, París, Gallimard.

VOELLMY, Jean (1989), René Char ou le mystère partagé, Seyssel, Champ Vallon.

WIESENTHAL, Mauricio (2015), Rainer Maria Rilke (El vidente y lo oculto), Barcelona, Acantilado.

WINKELVOSS, Karine (2004), Rilke, la pensée des yeux, pref. de Georges Didi-Huberman, París, Publications de l'Institut d'Allemand, Université de la Sorbonne Nouvelle. 